The Hidden Costs of Human Rights:

The Case of Immigration Detention

Global Detention Project Working Paper No. 7

By Michael Flynn

September 2013 
The Global Detention Project (GDP) is a research initiative that tracks the use of detention in response to global migration. Based at the Graduate Institute's Programme for the Study of Global Migration in Geneva, Switzerland, the GDP's aims include: (1) providing researchers, advocates, and journalists with a measurable and regularly updated baseline for analysing the growth and evolution of detention practices and policies; (2) encouraging scholarship in this field of immigration

studies; and (3) facilitating accountability and transparency in the treatment of detainees.

(C) Global Detention Project 2013

\author{
Global Detention Project \\ Programme for the Study of Global Migration \\ Graduate Institute of International and Development Studies \\ Rue de Lausanne 132 \\ P.O. Box 136 \\ $\mathrm{CH}-1211$ Geneva 21 \\ Switzerland \\ Tel: +41229084556 \\ Fax: +41229084594 \\ http://www.globaldetentionproject.org/
}

Michaeal Flynn is the founder and manager of the Global Detention Project based at the Graduate Institute's Programme for the Study of Global Migration (http://www.globaldetentionproject.org/). An abridged version of this paper appeared in the September 2013 issue of Forced Migration Review (http://www.fmreview.org/detention). Research for this paper was made possible in part by support from Zennström Philanthropies, the Oak Foundation, and the Open Society Foundations.

The Global Detention Project Working Paper Series is edited by Michael Flynn 


\title{
The Hidden Costs of Human Rights: The Case of Immigration Detention
}

\begin{abstract}
SUMMARY: Many liberal democracies betray a noticeable discomfort when it comes to public scrutiny of immigration detention, neglecting to release comprehensive statistics about it, cloaking detention practices in misleading names and phrases, and carefully choosing which activities they define as deprivation of liberty. On the other hand, these same countries have laboured to expand their detention activities and to encourage their neighbours to do the same. What explains this simultaneous reticence towards and embrace of immigration detention? This Global Detention Project working paper argues that a largely unrecognized variable influencing the evolution of immigration detention has been the promotion of some key human rights norms, which has helped spur states to adopt new institutions dedicated to this practice while at the same time prompting them to shift the burden of global migration to countries on the periphery of the international system.
\end{abstract}


"A comfortable, smooth, reasonable, democratic unfreedom prevails in advanced industrial civilization ..."

-Herbert Marcuse

THE T. DON HUTTO RESIDENTIAL CENTRE IS NOT A NURSING HOME. NOR IS IT a shelter for runaway children or a halfway house for recovering addicts. It is a privatelyrun for-profit immigration detention facility located near Austin, Texas, that confines undocumented female immigrants who are slated for deportation by the U.S.

Department of Homeland Security's Immigration and Customs Enforcement (ICE). Why is a migrant detention centre hidden behind a name? Answering this riddle can provide important clues about the forces shaping immigration detention policies today, particularly the role played by human rights norms.

\section{Adapting to human rights}

In October 2009, Manfred Nowak, then the UN Special Rapporteur on Torture, argued at a press conference that because states were failing in "their obligations to respect the basic dignity of human beings in detention," it was time to adopt a UN treaty on the rights of detainees. ${ }^{1}$ Among the vulnerable populations Nowak referred to were irregular migrants held in administrative detention, whose plight the UN High Commissioner for Human Rights Navi Pillay had claimed a month earlier-in September 2009_represented "one of today's most critical human rights challenges."

These pronouncements by two high-profile human rights advocates operating at the international level about the rights of immigration detainees highlight the intensifying global attention this practice has received in recent years. They also reflect an important factor influencing the evolution of immigration detention-the increasing diffusion of human rights norms relevant to the protection of non-citizens deprived of their liberty for reasons stemming from their immigration status. As states increasingly turn to detention to control their borders and immigrant populations, this practice is attracting the attention of an expanding number of rights advocates operating at the national, regional, and international levels.

The diffusion of immigration-related human rights has been fostered by the emergence since World War II of what some scholars call the "liberal epoch," a period that has seen the adoption of numerous international treaties that provide specific protections for noncitizens, like the UN Refugee Convention. As Lahav writes, "The 'liberal epoch' of human rights norms that facilitated humanitarian migration alongside labour recruitment

\footnotetext{
${ }^{1}$ Nowak, Manfred. "Press Conference by United Nations Special Rapporteur on Torture." UN Department of Public Information. New York. 20 October 2009.

${ }^{2}$ Pillay, Navanethem. "Opening Remarks at the Panel Discussion on Human Rights of Migrants in Detention Centers." UN Human Rights Council. Geneva. 17 September 2009.
} 
... contrasts with the preceding period. One only needs to recall the expulsions of 400,000 Poles from Germany in 1885-1886, or the exclusion of Chinese immigrants before the turn of the century in the United States to realize the normative evolution that has taken place in the migration policy domain." ${ }^{3}$

Sustaining the notion of a "liberal epoch" requires employing careful caveats that take into account the sometimes awful and inhuman conditions in which migrants can be detained across the globe, as well as the totalitarian conditions under which much of the globe lived during the purported formative years of this epoch. Nevertheless, Lahav points to an important aspect of contemporary international relations that needs to be considered when discussing the evolution of immigration detention regimes.

According to many scholars of globalisation, sovereign states are gradually "losing control" over their discretion on how to treat foreign-born residents because of the "emergence of an international human rights regime that prevents nation-states from deciding who can enter and leave their territory." 4 This Global Detention Project working paper aims to provide a subtler assessment of the impact of human rights norms. While it is indeed the case that certain norms - for example, the UN Refugee Convention's prohibition against refoulement of people who face persecution in their home countrieshave the effect of constraining state freedom of action with respect to certain categories of foreigners, the human rights framework relevant to non-citizens includes a host of norms that provide specific protections to immigration detainees without calling into question the states' sovereign right to detain or expel them.

This face-off between sovereign rights and human rights is resulting in a peculiar evolution of the detention phenomenon in which states employ adaptive mechanisms of adherence and avoidance. In other words, in their efforts to digest the bitter pill of human rights norms, states neither lose control nor gain more control. Rather, they adapt. It is this process of adaptation-or evolution—that this paper endeavours to explore.

\section{Hutto}

In April 2010 I visited Hutto at the invitation of U.S. Immigration and Customs Enforcement (ICE). ${ }^{5}$ For several years preceding my visit, the facility-which previously had been called the Hutto Family Residential Facility-was notorious for being one of only two U.S. sites used to detain families in what critics described as punitive conditions. Named after one of the U.S. pioneers in prison privatization and cofounder of

\footnotetext{
${ }^{3}$ Lahav, Gallya. "Migration and Security: the Role of Non-State Actors and Civil Liberties." United Nations Population Division, New York: UN/POP/MIG/2003.

${ }^{4}$ Guiraudon, V. and G. Lahav. "A Reappraisal of the State Sovereignty Debate: The Case of Migration Control." Comparative Political Studies. Vol. 33 No. 2, March 2000. p. 164.

${ }^{5}$ The author, in his capacity as lead researcher of the Global Detention Project, visited the T. Don Hutto Residential Center on 19 April 2010 at the invitation of the head of the Juvenile and Family Residential Management Unit of ICE's Detention and Removal Office (Dougherty 2010).
} 
the company that today owns Hutto (the Corrections Corporation of America), ${ }^{6}$ Hutto is located in a former prison that was converted to a family detention centre in 2006 at the behest of Congress.

Before Hutto opened, detained families in the U.S. tended to be either released from custody to await the termination of their immigration cases, or family members were placed in separate facilities: children were placed in the custody of the Office of Refugee Resettlement, parents were confined in detention centres. According to one account, when "Congress discovered this, it took immediate action to rectify the situation to ensure that ICE's practices were in keeping with America's tradition of promoting family values." In short, detaining families at Hutto was apparently meant to protect an important human right — the right to family life.

Almost overnight Hutto sparked heated debate in the United States about the treatment of undocumented immigrant children and families. ${ }^{8}$ In 2007, the American Civil Liberties Union (ACLU) successfully settled a lawsuit it had brought against ICE, which contended that conditions inside the detention centre violated standards for the treatment of minors in federal immigration custody. Two years later, in 2009, the Obama administration announced that it was officially ending the detention of children and families at Hutto, and converted the centre into an adult female-only detention facility.

By the time I arrived at Hutto in April 2010, the facility had undergone an intense makeover, becoming a centerpiece in the Obama administration's efforts to put a kinder, gentler face on detention (thus my invitation to visit it). Such was its apparent transformation from derided jailer of children to friendly lock up of immigrant women that one detainee I spoke with-a woman from Honduras who had previously been detained at other Texas detention centres-asked if I knew of any way to ensure that she would be detained again at Hutto in the event that she was apprehended during her next attempt to come to the United States (where her U.S.-born children lived). ${ }^{9}$

\footnotetext{
${ }^{6}$ T. Don Hutto cofounded with Tom Beasley and Robert Crants the Corrections Corporation of America (CCA) in 1983. In 1984, CCA opened the country's first privately-run detention center using a former hotel called the Olympic Motel. This temporary facility, which according to CCA was opened at the behest of INS, was replaced soon thereafter by the Houston Processing Center, "CCA's first design, build and manage contract from the U.S. Department of Justice for the Bureau of Immigration and Customs Enforcement (formerly the Immigration and Naturalization Service) in Texas" (CCA website, "A Quarter Century of Service to America").

${ }^{7}$ Women's Commission for Refugee Women and Children and Lutheran Immigration and Refugee Service. Locking Up Family Values: The Detention of Immigrant Families. February 2007, pp. 1-2.

${ }^{8}$ Helping spearhead local opposition to Hutto was an Austin, Texas-based group called Grassroots Leadership, http://www.grassrootsleadership.org/.

${ }^{9}$ It is important to note that while Hutto undertook a number of important reforms, the facility has continued to be plagued by scandals related to the treatment of detainees. In August 2010, for example, the ACLU launched an investigation into the alleged sexual abuse of detainees by CCA employees. In an August 2010 press release, the ACLU stated: "The sexual abuse of numerous immigration detainees at Hutto underscores the systemic failures that continue to plague our nation's broken immigration detention system. The irony is that ICE touts Hutto as a flagship facility, emblematic of its commitment to reform. Clearly, that commitment is shallow. ICE has ignored repeated calls for increased and independent oversight and accountability of its immigration detention facilities and the private contractors like CCA who run them, and tragedies like this are the unfortunate result. It is time for ICE officials to live up to their
} 
To reach Hutto, you have to drive through a low-income neighbourhood located on the outskirts of the small town of Taylor, Texas. After passing several blocks of run-down homes and abandoned barns, you come upon a large open field, at the end of which is a set of buildings surrounded by fences and barbed wire. Inside, the detention centre is comprised of several pods_or living areas_each with two levels of individual cells and an open area in the center. There is also a central cafeteria, a large gym, a library, a computer room, medical facilities, and outdoor recreation areas. Through the wide and high-ceilinged hallways one can observe inmates walking about freely from one section of the facility to the next, which they are allowed to do from early morning to early evening, when they must return to their cells.

During my visit, I was introduced to numerous staff representing both the Corrections Corporation of America and ICE, and given a personalized tour by the facility warden and a representative of ICE based at the facility. ${ }^{10}$ The tour included a visit to one of the pods. When we entered the pod, all the female detainees-apparently on cue and under orders-stood and began to clap, bringing a beaming smile to the face of the male warden.

After the tour, I sat with numerous facility staff, including several on-site medical personnel, to discuss my impressions. I acknowledged that Hutto appeared to be a well ordered and humanely-operated incarceration facility, and pointed out that surely the inmates at Hutto received better medical care than the people living in the surrounding community. One staff member commented that the working environment at Hutto was extremely warm and positive, and that this attitude had a positive impact on the demeanour of the detainees. I commented that while all the staff I had encountered indeed seemed quite cheerful, this fact struck me as disconcerting given the nature of their jobs. The warden then explained that the facility was able to have such an open and relaxed security environment because the women detained there were hand-picked based on their non-threatening profiles and track records. I asked why, if the women were not a threat, they were detained at such high costs in the first place, to which one of the staff responded-not without reason—that that was a question for the policymakers.

\section{Sovereign discomfort}

The peculiarities of Hutto are not unique to that facility. In fact, across the globe today one can find immigration detention centres hiding (and disclosing) their identities, operating under the management of a diverse array of state and non-state actors, and performing the apparent dual functions of assuaging public concern about immigration

promise of creating a 'truly civil' immigration detention system that does not tolerate the abuse and degradation of its detainees."

10 The author's visit to Hutto was overseen by ICE Supervisory Detention and Deportation Officer George Robertson. 
while signalling to would-be irregular migrants and asylum seekers that they are not welcome.

As with Hutto, the names of many of these facilities reveal contradictory official attitudes: Turkey has called its migrant detention centres "guesthouses"; Mexico uses "migratory stations" (estaciones migratorias) for the temporary housing (alojamiento temporal) of migrants; Hungary has "guarded shelters," Italy has "welcome centres" (centri di accoglienza), and France has "centres of administrative retention" (centres de rétention administrative).

Of course, not all countries use such creative terminology to describe their detention operations, but most states appear to view the penal nature of immigration detention as a source of embarrassment, a phenomenon one could term "sovereign discomfort."

This unease manifests itself in numerous ways and has long been at the heart of immigration detention regimes. For instance, what explains the paltry amount of statistical details regarding detention regimes? "A first difficulty that one encounters when attempting to present an overview of the use of immigration detention by [EU] Member States is to obtain reliable figures," writes Cornelisse. "If states do keep statistics, they are often rather reticent to make them available to the public."11

States commonly seek to de-link detention from incarceration, despite the natural affiliation between the two. A somewhat surprising example of this is provided by the Bahamian Department of Immigration on its website "Apprehension, Detention, and Deportation," which states: "While there may be widespread debate on the whole concept of detention, through its Detention Centre, the Department of Immigration maintains its stance that its centre is not a prison, but fundamentally acts as a holding facility for individuals who are found in contravention of the Immigration Rules and Regulations."

Bahamian legal traditions and detention policies have been shaped by two of the more important detaining countries in the world, the United Kingdom and the United States. And both of these countries-as well as other common law countries like Australiahave struggled to find legal justifications for this practice, in part because of what Wilsher terms the "uncomfortable recognition of the dissonance between immigration detention and liberal legal orthodoxy."12

Thus, while detention centres have clear symbolic and political roles, states have endeavoured-sometimes with the backing of rights actors- to soften the sharp edges of this practice, including by framing detention efforts with what Herbert Marcuse might characterize as a smile, à la Hutto.

\footnotetext{
${ }^{11}$ Cornelisse, Galina. Immigration Detention and Human Rights: Rethinking Territorial Sovereignty, Martinus Nijhoff Publishers. 2010. p. 7.

12 Wilsher, Dan. Immigration Detention: Law, History, Politics. Cambridge University Press. 2011, P. 56.
} 
This leads to a central question: Can the promotion of liberal norms have an unintended deleterious impact on how states' confront the challenges of irregular immigration?

\section{Institutionalisation and diffusion}

The concealing and revealing tendencies of states with respect to their detention practices can be observed in what this working paper argues are two outstanding characteristics of the contemporary immigration detention phenomenon: the gradual institutional entrenchment (or deepening) of migrant detention regimes in the nationstate (as observed, for example, in the shift from criminal prisons to dedicated immigration facilities) and the apparent spreading (or widening) of this practice across the globe. ${ }^{13}$ These developments appear to be driven by two processes: (1) the diffusion of normative regimes aimed at protecting non-nationals; (2) and the externalization of interdiction practices from core states of the international system to the periphery. As a result, we are witnessing the emergence of dedicated immigration detention regimes even in countries where there is little evidence of systematic efforts to detain as recently as 10 years ago.

Several recent cases help illustrate this argument. In early 2011, an official with the UN High Commissioner for Refugees described the Berks County Family Shelter-the similarly misleadingly named sister facility to Hutto which today is the only site in the United States that detains families - as the embodiment "of the best practices for a truly civil immigration detention model." The official explained that "UNHCR believes strongly that the vast majority of asylum seekers should not be detained," but in the event that asylum seekers are detained, Berks was the model to follow. ${ }^{14}$

By all accounts, Berks operates in a humane and "non-penal" manner, especially when compared to former operations at Hutto. However, while it is clearly important to applaud improvements in the treatment of detainees, is it a good idea for the international community's premier agency protecting asylum seekers to provide its imprimatur to efforts-even limited ones_-to detain them, including children? UNHCR, as a political and humanitarian entity, by necessity must at times walk a thin line between its treatybased mandate and the desires of its state partners. But this thesis argues that this sort of encouragement from a leading humanitarian agency provides "normative cover" for detention practices, shielding the state from uncomfortable questions regarding the right to liberty and helping entrench immigration detention into the institutional framework of the nation-state.

\footnotetext{
${ }^{13}$ The terms "deepening" and "widening" are frequently used in the context of the European Union to describe, respectively, the increasing levels of integration of its member states and its growing number of members. This paper adopts the terms to signify phenomenon with respect to immigration detention-the integration (or, institutionalization) of detention practices in the nation-state and the expanding number of states as well as non-state actors involved in this technology of immigration control-though not restricted to the European Union.

${ }^{14}$ UN High Commissioner for Refugees (UNHCR). 2011. "In Rural Pennsylvania, A Model of Civil Immigration Detention." UNHCR. 6 January 2011.
} 
Similarly, rights actors frequently focus their detention-related advocacy on promoting the proper treatment of detainees and applauding efforts by states to differentiate between criminal incarceration and the administrative detention of irregular migrants and asylum seekers. However, there is cause for concern that the emergence of specialized detention regimes can lead to increased use of detention in the face of growing international migration.

In contrast to the United States, most European countries ceased some time ago to use criminal facilities for the purposes of immigration detention, and the recent EU Returns Directive provides that member states must use specially planned facilities for confining people as they await deportation. But the process of shifting from informal to formal detention regimes, which has occurred over the last two decades, has paralleled the growth in immigration detention in this region.

Is there a connection between these two developments? The case of Ireland is illustrative. Ireland's immigration detention estate has been notable for two main reasons-its exceedingly small number of detainees each year (numbering in the dozens) and the fact that it has no official facility to confine these people. However, in 2006, after an official visit to the country, the Council of Europe's Committee for the Prevention of Torture admonished Ireland for detaining failed asylum seekers slated for deportation in prisons. The CPT pointed out that this treatment violated norms established in the European Convention on Human Rights. The CPT then recommended that Ireland build a facility that would be dedicated to this purpose. In its response, the government of Ireland promised to do just that, stating that it was in "ongoing discussions with the Irish Prison Service ... with the aim of providing a separate purpose built facility for immigration offenders at the new complex that conforms to best international standards."

As journalist Deepa Fernandes once wrote regarding the U.S. "immigration-industrial complex": "With the increase in prison beds to house immigrants comes the pressure to fill them." 15 Ireland thus represents an important test case for the future: With the shift to specialized facilities, will there be an uptick in the numbers of people detained?

At the same time that detention operations are becoming increasingly specialized in destination countries, these states are endeavouring to export interdiction efforts to other countries, raising questions about the evasion of their normative responsibilities. A case in point is the West African nation of Mauritania, which in 2006 opened its first dedicated detention centre for irregular migrants in the port city of Nouadhibou with assistance provided by the Spanish Agency for International Development Cooperation. The centre, which assists Mauritania's efforts to crack down on migrants using the country en route to the Canary Islands, was set up in a former school restored by Spanish authorities. Before 2006, in the rare instances that migrants were arrested by the police they were typically held at police stations. ${ }^{16}$

\footnotetext{
${ }^{15}$ Fernandes, D. Targeted: Homeland Security and the Business of Immigration. Seven Stories Press. New York: 2007. P. 199.

${ }^{16}$ Amnesty International. "Mauritania: Nobody Wants to Have Anything to Do With Us." 1 July 2008.
} 
Spain's involvement in establishing the detention centre has led to questions over who controls the facility and guarantees the rights of the detainees. While the centre is officially managed by the Mauritanian National Security Service, Mauritanian officials "clearly and emphatically" stated to a Spanish human rights organization in October 2008 that Mauritanian authorities perform their jobs at the express request of the Spanish government. ${ }^{17}$

The Mauritania case reflects a broader trend of core countries attempting to deflect migratory pressures by externalizing immigration controls to states that are not considered main destinations of migrants and where the rule of law is often weak. This raises questions about the culpability of liberal democracies in the abuses detainees suffer when they are interdicted before reaching their destinations. Observer have expressed similar concerns with respect to the numerous efforts to thwart the arrival of asylum seekers, such as EU discussions on extraterritorial processing centres, Australia's "Pacific Solution," and U.S. Caribbean interdiction policies.

\section{Unintended consequences}

Ultimately, this working paper argues that states' responses to relevant liberal norms are helping accelerate the institutionalization of detention in core destination countries and leading to the externalization of detention pressures and practices from the core to the periphery. On the one hand, norms regarding the proper treatment of detainees (those related to security of person) appear to be driving many destination countries to create specialized institutions that receive the blessing of rights watchdogs. At the same time, however, states increasingly seek to externalize interdiction efforts so as circumvent pressure stemming from norms that call into question the state's right to detain and deport, such as the right to liberty and prohibition of refoulement. ${ }^{18}$

What is at stake here is our understanding of the role human rights promotion plays in shaping state efforts to detain and deport undocumented migrants. Some scholars have argued that the practice of immigration detention is generating a normative discourse about the rights of non-citizens that has the potential to undermine the territorial basis of sovereignty and thereby "transform the international and domestic legal order into one that is more true to some of its underlying universalistic ideals." ${ }^{19}$

The indications discussed here seem to point to a different conclusion: That the promotion of the rights of migrant detainees reaffirms the territorial sovereignty of the nation-state in such a way as to ensure the increasing institutionalization and propagation of immigration-related detention into the foreseeable future.

\footnotetext{
${ }^{17}$ European Social Watch. "Spain: The Externalisation of Migration and Asylum Policies: The Nouadhibou Detention Center." 2009.

${ }^{18}$ For a fuller treatment of this argument, see Guiraudon and Lahav, ibid.

${ }^{19}$ Cornelisse ibid, p. 29.
} 
The right to personal liberty is one of the most powerful norms in the international community. As such, liberal states often betray a distinct discomfort when locking people up outside criminal processes. This sovereign discomfort takes on a number of peculiarities vis-à-vis the administrative detention of non-citizens for immigration-related reasons. States disguise the practice by using misleading terminology. They frequently limit access to detainees and fail to make available detailed statistics about detention. They selectively apply human rights norms that do not call into question the sovereign's right to detain and deport. They export detention pressures to the exterior so as to avoid norm-based responsibilities, like admitting asylum seekers. They endeavour to characterize many of the people subject to this form of detention in such a way as to spur public fears, and thereby justify locking migrants up. And, finally, they increasingly create legal institutions that criminalize irregular migration, thereby shifting this form of detention from an administrative to a criminal law framework.

For rights actors concerned about the growth of immigration detention, there may be an important lesson to be learned from this assessment. There appears to be a problematic aspect to the narrow promotion of the rights of migrant detainees. As such, migrant rights advocates arguably should consider de-emphasizing discourses that focus only on improving the situation of non-citizens in state custody and re-emphasizing the taboo against depriving anyone of his or her liberty without charge. Instead of spurring states to create special institutions - or standard operating procedures-for keeping migrants in their custody, advocates should work to ensure that any limitation on freedom remains the exception to the rule. 


\section{Bibliography}

Amnesty International. "Mauritania: Nobody Wants to Have Anything to Do With Us." 1 July 2008.

Cornelisse, Galina. Immigration Detention and Human Rights: Rethinking Territorial Sovereignty. Martinus Nijhoff Publishers. 2010.

Corrections Corporation of America (CCA). Website. "A Quarter Century of Service to America." http://www.cca.com/about/cca-history/ (accessed 1 October 2013).

Dougherty, Deane, (ICE Office of Detention and Removal), Andrew Lorenzen-Strait (ICE Office of Policy), et al. Interview with Michael Flynn in Washington, D.C. Global Detention Project. 16 April 2010.

European Social Watch. "Spain: The Externalisation of Migration and Asylum Policies: The Nouadhibou Detention Center." 2009.

Fernandes, D. Targeted: Homeland Security and the Business of Immigration. Seven Stories Press. New York: 2007.

Guiraudon, V. and G. Lahav. "A Reappraisal of the State Sovereignty Debate: The Case of Migration Control." Comparative Political Studies. Vol. 33 No. 2, March 2000.

Lahav, Gallya. "Migration and Security: the Role of Non-State Actors and Civil Liberties." United Nations Population Division, New York: UN/POP/MIG/2003.

Nowak, Manfred. 2009. "Press Conference by United Nations Special Rapporteur on Torture." UN Department of Public Information. New York. 20 October 2009.

Pillay, Navanethem. 2009. "Opening Remarks at the Panel Discussion on Human Rights of Migrants in Detention Centers." UN Human Rights Council. Geneva. 17 September 2009.

UN High Commissioner for Refugees (UNHCR). "In Rural Pennsylvania, A Model of Civil Immigration Detention." UNHCR. 6 January 2011.

Women's Commission for Refugee Women and Children and Lutheran Immigration and Refugee Service. Locking Up Family Values: The Detention of Immigrant Families. February 2007.

Wilsher, Dan. Immigration Detention: Law, History, Politics. Cambridge University Press. 2011. 